\title{
Magdalena Dudkiewicz
}

\section{Sektor obywatelski i obywatelscy aktywiści w czasach „dobrej zmiany”. \\ Dyskusje - napięcia - konflikty}

\section{Wprowadzenie}

„Boję się, boję się rozlewu krwi w naszym kraju, bo coraz częściej członkowie rodziny skaczą sobie do gardeł, nawet przy wigilijnym stole. Trzeba uważać, kiedy, co i komu się mówi. Nawet w żartach". Ten cytat, pochodzący z raportu zatytułowanego Wyzwania $i$ zagrożenia pracy $w$ NGO $i$ nieformalnych ruchach społecznych ${ }^{1}$ dobrze oddaje częste $\mathrm{w}$ różnych środowiskach obawy i dylematy. Pochodzi od osoby biorącej udział w badaniach dotyczących wypalenia zawodowego w sektorze pozarządowym, który także doświadcza powszechnych $\mathrm{w}$ ostatnich latach podziałów w naszym społeczeństwie. Doświadcza ich niejako w dwójnasób - sektor

Magdalena Dudkiewicz (ORCID: 0000-0002-8505-0036) - doktor habilitowana z dziedziny socjologii, adiunkt w Instytucie Stosowanych Nauk Społecznych Uniwersytetu Warszawskiego, gdzie prowadzi zajęcia z zakresu organizacji pozarządowych oraz realizacji projektu badawczego i animacji kultury w środowisku lokalnym. Badaczka organizacji pozarządowych. W latach 2005-2020 sekretarz redakcji kwartalnika „Trzeci Sektor”. Kontakt: madud@gazeta.pl.

1 M. Cypryańska-Nezlek, Wyzwania i zagrożenia pracy w NGO $i$ nieformalnych ruchach spotecznych. Raport z badania, Biuro Rzecznika Praw Obywatelskich, 25 lutego 2020, https://www. rpo.gov.pl/sites/default/files/Raport\%20z\%20badania\%20Marzena\%20Cyprya\%C5\%84ska-Nezlek_0.pdf (dostęp: listopad 2020). 
pozarządowy to przecież zwyczajni członkowie naszych wspólnot - rodzinnych, lokalnych, zawodowych - a jednocześnie to konkretne, specyficzne środowisko, w czasach „dobrej zmiany” poddawane gwałtownemu upolitycznieniu.

Upolitycznienie i wynikające z niego podziały oczywiście nie dotyczą tylko tego środowiska. Począwszy od najbardziej widocznego i poruszającego opinię publiczną konfliktu w środowiskach prawniczych (zwłaszcza sędziowskich), przez szeroko rozumiane środowiska artystyczne, aż do najbliższych mi na co dzień środowisk naukowych i uczelnianych. I oczywiście wielu, wielu innych.

Na początku konieczne jest wskazanie mojej zróżnicowanej relacji z każdym z wymienionych środowisk. Najdalej mi do artystów - ich spory docierają do mnie jedynie w przekazach medialnych (które w różnym stopniu odgrywają rolę we wszystkich wskazanych przeze mnie kategoriach). W odniesieniu do środowisk prawniczych dochodzi do tego zaangażowanie w protesty (demonstracje, petycje) oraz, w pewnym stopniu, przenikanie ze środowiskiem akademickim. Najbliżej mi do tego ostatniego, a także do - będącego najważniejszym przedmiotem niniejszych rozważań - środowiska organizacji pozarządowych. Przy czym w życiu środowiska akademickiego uczestniczę z racji pozycji zawodowej, a w tym, co dotyczy organizacji - z racji wieloletniego zaangażowania eksperckiego i badawczego. Najważniejsze źródło wiedzy o tym, jakie są konsekwencje „dobrej zmiany” w sektorze pozarządowym stanowią badania przeprowadzone w 2019 roku wspólnie z Magdaleną Arczewską².

W tym miejscu istotne wydaje mi się podkreślenie ważnej konsekwencji tak zróżnicowanego oglądu sytuacji poszczególnych środowisk, do których się tu odnoszę. Wynika z niego swoista niespójność niniejszego opracowania: ze względu na brak danych będących wynikiem oglądu naukowego wiele elementów analizy w oczywisty sposób nie spełnia klasycznych kryteriów naukowych i w znaczącym stopniu wpisuje się w dyskurs o charakterze publicystycznym. Jednocześnie należy je potraktować jako swoiste wołanie o dokonanie refleksji naukowej w tej kwestii, co jednak

2 Wyniki tego badania, wraz z notą metodologiczną, zostaną przedstawione w drugiej części artykułu. 
obecnie - w czasie skupienia większości badań na zupełnie innej okoliczności wpływającej na funkcjonowanie polskiego społeczeństwa, czyli funkcjonowania w czasie i po pandemii Covid-19 - wydaje się jednak mało realne.

\section{Podzielone społeczeństwo}

Zanim zajmę się konkretnymi środowiskami, zacznijmy od ogólnego tła społecznego. Polaryzacja społeczna jest procesem, który najprościej można zdiagnozować i scharakteryzować na podstawie obserwacji gwałtownie różnicujących się postaw osób należących do konkretnych zbiorowości wobec pewnego typu problemów; dodajmy: takich, które dotyczą ważnych i powszechnie dostrzeganych (często ze względu na intensywną obecność w mediach) sfer życia społecznego. Podczas polaryzacji tworzą się zazwyczaj w szybkim czasie dwa obozy - przeciwników i zwolenników rozwiązania danego problemu społecznego, przy czym maleje liczba osób wyrażających postawy umiarkowane. Za szczególny rodzaj polaryzacji społecznej należy uznać polaryzację polityczną, która, jak wynika z badań przeprowadzonych przez Centrum Badań nad Uprzedzeniami ${ }^{3}$, cechuje się w polskim społeczeństwie wysokim wskaźnikiem negatywnych uczuć wobec osób o przeciwnych preferencjach wyborczych. Dokonane przez badaczy pomiary dotyczyły temperatury uczuć, zaufania, dehumanizacji, kontaktu międzygrupowego i moralizacji postaw.

Podział społeczno-polityczny w Polsce jest coraz bardziej widoczny i wydaje się trwały. Na jego gruncie toczy się konflikt polityczny o podłożu ideologiczno-aksjologicznym. Jego skutki można dostrzec w wielu sferach życia społecznego, w codziennym doświadczeniu, w praktyce organizacyjnej i wreszcie w wymiarze aksjologicznym ${ }^{4}$. Jak pisze Piotr Radkiewicz:

3 P. Górska, Polaryzacja polityczna w Polsce. Jak bardzo jesteśmy podzieleni?, Centrum Badań nad Uprzedzeniami, Warszawa 2019, https://docplayer.pl/115461613-Polaryzacja-polityczna -w-polsce-jak-bardzo-jestesmy-podzieleni-paulina-gorska.html (dostęp: listopad 2020).

4 P. Obacz, Podziat społeczno-polityczny w Polsce - wymiar aksjologiczny. Istota, konsekwencje, prognozy, w: E. Starzyńska-Kościuszko (red.), Wartości $i$ wartościowanie we wspótczesnej humanistyce. Perspektywa filozoficzna, Centrum Badań Europy Wschodniej Uniwersytetu Warmińsko-Mazurskiego, Olsztyn 2017. 
[...] polityczny konflikt i polaryzacja społeczna w Polsce to przejawy fundamentalnej „wojny kulturowej”. [...] Warto zastanowić się nad społeczno-polityczną stawką wspomnianej wojny. A jest nią - jak wiele na to wskazuje - kształt polskiej demokracji. Od listopada 2015 roku, tj. od przejęcia rządu przez Zjednoczoną Prawicę (PiS + Polska Razem + Solidarna Polska), bardzo wiele napisano i powiedziano o różnicach dzielących demokrację liberalną od demokracji nieliberalnej (nazywanej niekiedy „suwerenną”). Różnice te można dość łatwo dostrzec w treści stanowionego prawa, stosunku do instytucji państwa czy w tzw. pragmatyce rządzenia. Modelowe rozwiązania tych konkurencyjnych pomysłów na demokrację, ze wszystkimi ich zaletami i wadami, są doskonale znane ${ }^{5}$.

Autor wskazuje na istotne z punktu widzenia niniejszego opracowania cechy konfliktu politycznego w Polsce, takie jak eskalacja, gwałtowność, intensywność, znaczny poziom wzbudzanych emocji i negatywny wpływ na relacje międzyludzkie, destrukcyjność oraz rozlanie, a cechy te uznaje za wskazujące na źródło konfliktu ulokowane w „zderzeniu dwóch antagonistycznych systemów aksjologicznych"6. Chociaż w konkretnych konfliktach (takich jak protest w Sejmie rodziców niepełnosprawnych osób dorosłych, reakcja władz na kryzys uchodźczy, strajk nauczycieli, zjawisko pedofilii w Kościele, a w ostatnim czasie kwestia przekazania 2 mld zł na media publiczne) społeczeństwo nie podzieliło się na dwie mniej więcej równe części, to jednak za rozstrzygające można uznać wyniki wyborów parlamentarnych z 2019 roku, które pokazują, że generalnie ów podział wygląda właśnie tak: albo jest się za obecną władzą, albo przeciw ${ }^{7}$. Taki stan rzeczy prowadzi niektórych publicystów wręcz do stwierdzenia, że „[...] w obecnych wyborach prezydenckich istnieje tylko jeden fundamentalny spór. Dotyczy on tego, czy Polska w ogóle powinna być państwem prawa, czy państwem jednej partii”".

$5 \quad$ P. Radkiewicz, Wzorce preferowanych wartości a wybory polityczne. O aksjologicznych przesłankach polaryzacji politycznej Polaków, w: A. Pytka, K. Maciąg (red.), Rozważania na temat kondycji polskiego społeczeństwa, Wydawnictwo Naukowe Tygiel, Lublin 2018, s. 34, dostępne na: http://bc.wydawnictwo-tygiel.pl/public/assets/239/Rozwa proc.C5 proc.BCania proc.20na proc.20temat proc.20kondycji proc.20polskiego proc.20spo proc.C5 proc.82ecze proc.C5 proc.84stwa.pdf (dostęp: listopad 2020).

6 Ibidem, s. 37.

7 Wybory do Sejmu i Senatu Rzeczypospolitej Polskiej 2019, Państwowa Komisja Wyborcza, https://sejmsenat2019.pkw.gov.pl/sejmsenat2019/ (dostęp: listopad 2020).

8 T. Sawczuk, Kampania prezydencka to strata czasu, „Kultura Liberalna” 2020, nr 8, dostępne na: https://kulturaliberalna.pl/2020/03/02/sawczuk-w-poniedzialek-kampania-prezydenckato-strata-czasu/ (dostęp: listopad 2020). 


\section{Podzielone środowiska}

Wskazane wyżej przykłady istotnych konfliktów w różnym stopniu interesują i angażują całe społeczeństwo. Na taki stan rzeczy nakładają się istotne podziały w konkretnych środowiskach. Specyficzną i - nomen omen - medialną ich odmianę stanowi spór w środowisku dziennikarskim, dość klarowny ze względu na to, że dziennikarze zwykle albo pracują dla mediów publicznych (lub takich, które są ideowo i kapitałowo powiązane z obecnie rządzącą formacją polityczną), albo dla pozostałych. Prowadzi to nawet do problematyzowania takich pojęć jak dziennikarstwo (versus propaganda) czy media publiczne (versus media rządowe) ${ }^{9}$. Ten spór widoczny jest też w środowisku ludzi sceny i estrady, również stających przed dylematem, czy należy brać udział w przedsięwzięciach Polskiego Radia i Telewizji ${ }^{10}$ (programach, serialach, koncertach plenerowych itp. ${ }^{11}$ ), ale także jednoznacznego opowiadania się za lub przeciw władzy, co w pewnym stopniu przypomina dylematy z okresu PRL ${ }^{12}$. Dużym zainteresowaniem mediów cieszą się kolejne konflikty wokół wielkich placówek muzealnych, zwłaszcza Muzeum II Wojny Światowej w Gdańsku (usunięcie w 2017 roku z funkcji dyrektora Pawła Machcewicza ${ }^{13}$ ), w Muzeum Narodowym w Warszawie (skutków nominacji i ostatecznie odwołania

9 M. Jethon, M. Czajkowski: Media publiczne w Polsce to sq media rzadowe, Koduj24.pl, 24 czerwca 2019, https://koduj24.pl/maciej-czajkowski-media-publiczne-w-polsce-to-samedia-rzadowe/ (dostęp: listopad 2020).

10 Wiosną 2020 roku na pierwszy plan wysunął się konflikt i poważny kryzys wywołany w III Programie Polskiego Radia spowodowany zakwestionowaniem przez władze rozgłośni wyników notowania Listy Przebojów, które wygrał utwór Kazika Staszewskiego Twój ból jest lepszy niż mój. [adm], Lista Przebojów Trójki zawieszona. Ale wygrat Kazik, „Rzeczpospolita”, 22 maja 2020, dostępne na: https://www.rp.pl/Media/200529718-Lista-Przebojow-Trojki-zawieszona -Ale-wygral-Kazik.html (dostęp: listopad 2020).

11 E. Rutkowska, Piotr Battroczyk nie chce występować w TVP rzadzonej przez Jacka Kurskiego, Press, 10 maja 2016, https://www.press.pl/tresc/43834,piotr-baltroczyk-nie-chce-wystepowac -w-tvp-rzadzonej-przez-jacka-kurskiego (dostęp: listopad 2020).

12 Matka Kurka [Piotr Wielgucki], Gorzej niż za komuny, powiedziat aktor $z$ PRL-u, Kontrowersje.net, 1 maja 2018 https://www.kontrowersje.net/gorzej_ni_za_komuny_powiedzia_aktor_ z_prl_u (dostęp: listopad 2020).

13 E. Flieger, „To Muzeum powinno być duma”. Proces pokazuje, jak prawica niszczyła Muzeum II Wojny Światowej, OKO.Press, 24 listopada 2019, https://oko.press/to-muzeum-powinno-byc -duma-proces-pokazuje-jak-prawica-niszczyla-muzeum-ii-ws/ (dostęp: listopad 2020). 
po wielkim konflikcie z funkcji dyrektora Jerzego Miziołka ${ }^{14}$ ) czy długiego okresu niejasnej sytuacji w Muzeum Żydów Polskich Polin (niepowołania na stanowisko dyrektora Dariusza Stoli, mimo jednoznacznie wygranego konkursu $\left.{ }^{15}\right)$. O temperaturze sporów - mających, co należy zaznaczyć, charakter nie tylko personalny, lecz także merytoryczny - świadczy fakt, że wiele tych konfliktów już znajduje lub niebawem znajdzie finał w sądach. Nie sposób wreszcie pominąć sporu, który z mniejszą lub większą intensywnością przez ostanie lata towarzyszy nam nieustająco, czyli zmian w wymiarze sprawiedliwości (najpierw w odniesieniu do Trybunału Konstytucyjnego, a obecnie ustroju sądów powszechnych). To spór, który, chociaż toczony przede wszystkim w środowisku prawników, jednak dotyczy nas wszystkich, a wielu obywateli mocno - zresztą po obu stronach - angażuje ${ }^{16}$.

Jak już wspomniałam, spór o muzea jest także sporem merytorycznym, o wizję polskiej historii. Analogiczny spór toczą naukowcy z dziedziny nauk społecznych, zwłaszcza socjologowie ${ }^{17}$ i prawnicy ${ }^{18}$. Najczęściej ujawnia się on w formie uchwał rad wydziałów szkół wyższych lub stanowisk stowarzyszeń naukowych, często oficjalnie (także w drodze uchwały)

14 P. Sarzyński, Prof. Miziołek niczym tajfun rujnuje Muzeum Narodowe, „Polityka”, 11 lipca 2019, dostępne na: https://www.polityka.pl/tygodnikpolityka/kultura/1799838,1,prof-miziolek-niczym-tajfun-rujnuje-muzeum-narodowe.read (dostęp: listopad 2020).

15 Spór o dyrektora Polin: Ministerstwo Kultury odpowiada na oświadczenie Dariusza Stoli, Onet Kultura, 11 lutego 2020, https://kultura.onet.pl/wiadomosci/spor-o-dyrektora-polinministerstwo-kultury-odpowiada-na-oswiadczenie-dariusza-stoli/9h33y8v (dostęp: listopad 2020).

16 [tmw/kg], Protesty w obronie sadów w polskich miastach. Zobacz, jak wygladaty, TVN24.pl, 18 grudnia 2019, https://tvn24.pl/polska/protesty-w-obronie-wolnych-sadow-demonstracje-w-polskich-miastach-ra994396-2608984 (dostęp: listopad 2020); M. Kryszkiewicz, G. Osiecki, Dokad zmierzamy w sporze o sady? 12 pytań $i$ odpowiedzi dotyczacych uchwaty Sądu Najwyższego, „Gazeta Prawna”, 27 października 2020, dostępne na: https://prawo.gazetaprawna.pl/artykuly/1450531,uchwala-sadu-najwyzszego-spor-o-sady.html (dostęp: listopad 2020); [MK] Demonstracja poparcia dla reformy sądownictwa. „Jako społeczeństwo musimy coś zrobić, TVP Info, 2 lutego 2020, https://www.tvp.info/46470541/demonstracja-poparcia-dla -reformy-sadownictwa-jako-spoleczenstwo-musimy-cos-zrobic (dostęp: listopad 2020).

17 M. Pawlak, List socjologów do wicepremiera Glińskiego w sprawie demokracji, petycjeonline. com, styczeń 2016, https://www.petycjeonline.com/list_socjologow_do_wicepremiera_glinskiego_w_sprawie_demokracji (dostęp: listopad 2020).

18 Uchwała nr 01/12/2017 Rady Wydziatu Prawa i Administracji Uniwersytetu Warszawskiego w sprawie apelu do Prezydenta Rzeczypospolitej Polskiej, http://strony.wpia.uw.edu.pl/zarzadzeniauchwaly/files/2017/12/201712201444_0001.pdf (dostęp: listopad 2020). 
popieranych przez kolejne jednostki uczelniane. Na ten spór merytoryczny w interesujący sposób nakładają się też gorące dyskusje dotyczące zapisów ustawy o szkolnictwie wyższym, istotnie odmieniającej sposób funkcjonowania polskich uczelni ${ }^{19}$.

Przytoczone wyżej przykłady sporów ideowo-politycznych pokazują, z jak silnym i wielowątkowym podziałem mamy do czynienia. Głównym tematem niniejszego tekstu jest zdiagnozowany w badaniach podział w sektorze polskich organizacji pozarządowych oraz sposób, w jaki sytuacja w tym środowisku łączy się z ogólniejszymi podziałami w polskim społeczeństwie.

\section{Sektor obywatelski - od obserwacji i publicystyki do badania naukowego}

Sektor pozarządowy nie działa w próżni. Więcej - w pewnym sensie stanowi swoistą reprezentację aktywnych społecznie obywateli, ze wszystkimi zróżnicowaniami: demograficznymi, terytorialnymi, interesów, i wreszcie - co najważniejsze - światopoglądowymi. Ciekawy kontekst stwarza pod tym względem osoba Piotra Glińskiego, stanowiąca istotny kontrapunkt dla sporów naukowych (jest uznanym naukowcem - profesorem socjologii), w zakresie władzy politycznej (jest wicepremierem w kolejnych rządach zjednoczonej prawicy), w odniesieniu do funkcjonowania instytucji kultury (jest ministrem kultury w rządzie „dobrej zmiany”) oraz sporów dotyczących modelu społeczeństwa obywatelskiego (jest pomysłodawcą i twórcą Narodowego Instytutu Wolności - Centrum Rozwoju Społeczeństwa Obywatelskiego), co dla dalszych rozważań ma znaczenie kluczowe.

Wokół powstania Narodowego Instytutu Wolności toczył się gorący spór. Po ogłoszeniu inicjatywy jego utworzenia wskazywano, że nie był to postulat pochodzący od środowiska pozarządowego oraz że przy tworzeniu ustawy i nowej instytucji nie przeprowadzono w tym środowisku odpowiednich konsultacji. Obawiano się centralizacji agend rządowych rozdzielających środki publiczne dla organizacji pozarządowych i tym

19 Prawo o szkolnictwie wyższym i nauce, Konstytucja dla Nauki, https://konstytucjadlanauki.gov. pl/ (dostęp: marzec 2020). 
samym ograniczenia ich swobody oraz upolitycznienia decyzji w tym zakresie $^{20}$. Do pewnego stopnia obawy te się spełniły, o ile jednak w działaniach (w tym decyzjach personalnych i finansowych) Piotra Glińskiego jako ministra kultury sposób działania bywa uznawany za jednoznacznie destrukcyjny $^{21}$, o tyle w odniesieniu do organizacji pozarządowych kwestia jest bardziej złożona. Gwoli ścisłości należy dodać, że być może przeprowadzenie badań w instytucjach kultury, które doświadczają skutków decyzji ministerialnych, także zniuansowałoby ocenę ostatnich kilku lat.

Takimi wynikami nie dysponuję, natomiast wraz z Magdaleną Arczewską - jako wieloletnie uczestniczki, ekspertki i badaczki sektora obywatelskiego w Polsce - postanowiłyśmy nasze obserwacje zmian, jakich doświadcza on od momentu rozpoczęcia tak zwanej dobrej zmiany przekuć w refleksję naukową: przeprowadziłyśmy badania. Część ilościowa została zrealizowana na nasze zlecenie przez Stowarzyszenie Klon/Jawor, badania jakościowe przeprowadziłyśmy samodzielnie. Projekt został sfinansowany ze środków Instytutu Stosowanych Nauk Społecznych Uniwersytetu Warszawskiego, w którym obie od lat pracujemy.

\section{Czy „dobra zmiana” w organizacjach? Badania i analizy}

Organizacje pozarządowe (społeczne), podmioty społeczeństwa obywatelskiego, trzeci sektor, to od zawsze raczej pojęcia analityczne i prawne niż zbiór dający się jednoznacznie wyodrębnić i scharakteryzować. W Polsce jest zarejestrowanych ponad 140 tys. stowarzyszeń i fundacji, z których ponad 100 tys. jest faktycznie aktywnych. Oprócz tego istnieje około 50 tys. podmiotów reprezentujących inne formy społecznego zaangażowania, wśród nich między innymi związki zawodowe, spółdzielnie socjal-

20 P. Kośmiński, Ustawa o Narodowym Instytucie Wolności czeka na podpis Andrzeja Dudy. NGO-sy apeluja o kolejne weto, Wyborcza.pl, 6 października 2017, https://wyborcza.pl/ 7,75398,22476571,apel-do-andrzeja-dudy-o-zawetowanie-ustawy-o-ngo-sach-grozi.html (dostęp: listopad 2020).

21 K. Wojciechowski, Dobra zmiana w kulturze: Pomnażać i centralizować, Dziennik.pl, 4 października 2019, https://kultura.dziennik.pl/news/artykuly/609380,dobra-zmiana-kulturapiotr-glinski.html (dostęp: listopad 2020). 
ne, organizacje pracodawców, koła gospodyń wiejskich, kółka rolnicze, cechy rzemieślnicze, instytucje kościelne i partie polityczne ${ }^{22}$.

Trudno odnaleźć jakąkolwiek cechę jednoznacznie dającą się przypisać każdemu podmiotowi, który jest zaliczany do tego zbioru ${ }^{23}$, ponieważ sektor pozarządowy z natury rzeczy jest wolnościowy, a w konsekwencji - skrajnie zróżnicowany. Z punktu widzenia niniejszych rozważań kluczowe jest zróżnicowanie ideowe i światopoglądowe. Najprościej można to pokazać na przykładzie działania organizacji, których misje w oczywisty sposób się wykluczają, jak na przykład w przypadku podmiotów działających na rzecz świadomego macierzyństwa (tzw. pro-choice) i organizacji starających się o wprowadzenie całkowitego zakazu aborcji (tzw. pro-life). Jedne i drugie podlegają tym samym przepisom, zasadom pozyskiwania funduszy oraz regulacjom dotyczącym tak istotnych praktycznych aspektów działania jak zatrudnianie wolontariuszy czy zbiórki publiczne.

Celem naszych badań było dokonanie naukowej refleksji nad sytuacją sektora pozarządowego po blisko pięciu latach rządów zjednoczonej prawicy. Punktem wyjścia były inne odnalezione opracowania na ten temat, ale nie było ich wiele. Do najważniejszych należy najbardziej aktualna edycja raportu Kondycja organizacji pozarządowych ${ }^{24}$, rekonstruująca stan na rok 2018. Jedno z poruszanych w raporcie zagadnień dotyczyło stosunku organizacji do rządu oraz podziałów ideologicznych w sektorze pozarządowym. Jak wynika z raportu, bardzo wiele organizacji odmawiało udzielenia odpowiedzi na pytania związane z tymi zagadnieniami, jednak za istotny wynik należy uznać formułowaną przez organizacje

22 Fakty o NGO, ngo.pl, https://fakty.ngo.pl/ (dostęp: marzec 2020).

23 Zob. m.in.: J. Kurczewski, Lokalne społeczeństwa obywatelskie, w: idem (red.), Lokalne społeczności obywatelskie, Instytut Stosowanych Badań Społecznych, Warszawa 2003, s. 252; P. Gliński, H. Palska, Cztery wymiary społecznej aktywności obywatelskiej, w: H. Domański, A. Rychard (red.), Elementy nowego ładu, Instytut Filozofii i Socjologii PAN, Warszawa 1997, s. 365-366; A. Siciński, Społeczeństwo obywatelskie a polskie transformacje ustrojowe, w: E. Muszyńska, I. Pielak (red.), Ludzie i instytucje. Stawanie się ładu społecznego. Pamiętnik IX Ogólnopolskiego Zjazdu Socjologicznego, Wydawnictwo Uniwersytetu Marii Curie-Skłodowskiej, Lublin 1995, s. 115; J. Szacki: Historia myśli socjologicznej. Wydanie nowe, Wydawnictwo Naukowe PWN, Warszawa 2002, s. 465.

24 B. Charycka, M. Gumkowska, Kondycja organizacji pozarzadowych. Raport z badań 2018, Stowarzyszenie Klon/Jawor, Warszawa 2019, dostępne na: https://api.ngo.pl/media/get/108227 (dostęp: marzec 2020). 
ocenę warunków, w jakich funkcjonowały w 2017 roku: w całym sektorze pozarządowym tak dużej grupy organizacji negatywnie oceniających miniony rok (miniony - bo organizacje wypowiadały się w 2018 roku) nie było od dekady. Blisko 77 proc. organizacji ocenia, że w 2017 roku sytuacja organizacji pozarządowych nie poprawiła się w stosunku do poprzednich lat, a 15 proc. organizacji twierdzi, że wręcz się pogorszyła. Okazało się również, że optymistyczna lub pesymistyczna ocena teraźniejszości i wizja przyszłości w pewnym stopniu koreluje ze stosunkiem do obecnych władz w Polsce. Autorki raportu - Beata Charycka i Marta Gumkowska - przypisały poszczególnym grupom organizacji wyodrębnionych w badaniu określenia „organizacje prorzadowe” i „organizacje antyrzadowe”, a także „organizacje zakonspirowane” (odmawiające odpowiedzi na konkretne pytania) oraz „organizacje wstrzemięźliwe” (najczęściej nie wypowiadające się ani za, ani przeciw). Wyraźna różnica w ocenach między organizacjami prorządowymi i antyrzqdowymi wskazuje na ważny podział: te pierwsze ponad dwa razy częściej niż te drugie uznają, że ich sytuacja polepszyła się w stosunku do roku poprzedniego oraz ponad dwa razy częściej spodziewają się, że kolejny rok będzie jeszcze lepszy: jest lepiej niż było, a będzie jeszcze lepiej. $Z$ kolei organizacje antyrzadowe dwa razy częściej niż prorzadowe spodziewają się gorszego następnego roku. Istnieje jednak grupa organizacji, które ten sam rok oceniają jeszcze krytyczniej. To „organizacje równościowe, które działają na rzecz równości, ochrony praw i wolności człowieka, ochrony mniejszości, zapewnienia równości szans, równych praw kobiet i mężczyzn, przeciwdziałają dyskryminacji”25.

Sytuację, w której znalazły się organizacje pozarządowe w wyniku „dobrej zmiany” analizuje także Filip Pazderski ${ }^{26}$, który pisze o „problemach ze stabilnością finansową (i różnorodnością źródeł wsparcia) oraz $\mathrm{z}$ dostępem do środków publicznych (zwłaszcza pochodzących z Unii

25 B. Charycka, Zmobilizowane przez trudności, ngo.pl, 3 kwietnia 2019, https://publicystyka. ngo.pl/zmobilizowane-przez-trudnosci. Zob. też M. Arczewska, B. Charycka, M. Gumkowska, Kondycja organizacji równościowych. Raport z badań 2019, Stowarzyszenie Klon/Jawor, Warszawa 2019, dostępne na: https://api.ngo.pl/media/get/110722.

26 F. Pazderski, Organizacje obywatelskie w Polsce wobec wyzwań społeczno-politycznych $i$ nowych trendów w ich rozwoju, w: R. Boguszewski (red.), Społeczeństwo obywatelskie w teorii i praktyce, Wydawnictwo Szkoły Głównej Gospodarstwa Wiejskiego, Warszawa 2018, s. 105-128. 
Europejskiej), a także o braku świadomości potrzeb trzeciego sektora w społeczeństwie i we władzach"27. Autor potwierdza wniosek dotyczący szczególnej kategorii organizacji, wyodrębnionej w raporcie Charyckiej i Gumkowskiej: „organizacje obywatelskie zajmujące się prawami człowieka, zwłaszcza wsparciem różnych grup mniejszościowych, znalazły się w najgorszej sytuacji, ponieważ znacznie ograniczono im w ostatnich latach dostęp do środków publicznych, a nie mają wielu innych możliwości uzyskania wsparcia finansowego" ${ }^{28}$. Powołując się na opinie eksperckie oraz dane gromadzone w ramach repozytorium Ogólnopolskiej Federacji Organizacji Pozarządowych ${ }^{29}$ wskazuje na istotne negatywne czynniki prowadzące do utrudnienia działalności organizacji po 2015 roku, wymieniając między innymi: ograniczanie dialogu publicznego z organizacjami, w tym konsultacji społecznych, uchybienia proceduralne w przyznawaniu środków publicznych przez organy administracji rządowej, uruchomioną pod koniec 2016 roku kampanię w mediach publicznych, w której wybrane organizacje przedstawiano jako powiązane $\mathrm{z}$ opozycją polityczną i nieuczciwe, a także scentralizowanie administracji nad sektorem społeczeństwa obywatelskiego poprzez powstanie Narodowego Instytutu Wolności ${ }^{30}$. Podobne wnioski zawiera między innymi XI Komunikat Obywatelskiego Forum Legislacji, w którym przedstawiono nieprawidłowości procesu legislacyjnego w sferze sektora obywatelskiego ${ }^{31}$.

Z punktu widzenia naszego projektu badawczego szczególnie istotne były też wnioski Filipa Pazderskiego dotyczące wyzwań, które opisana sytuacja stawia przed organizacjami pozarządowymi oraz sposobów, w jakie starają się one im sprostać. Autor wskazuje na dwa sposoby radzenia sobie w sytuacji ograniczania funduszy publicznych, jednocześnie podkreślając, że świadczą one o istnieniu „potencjału przeciwdziałania głównym

27 Ibidem.

28 Ibidem, s. 114.

29 https://repozytorium.ofop.eu/ (dostęp: marzec 2020).

30 F. Pazderski, Organizacje obywatelskie..., s. 115.

31 G. Kopińska (red.), XI Komunikat Obywatelskiego Forum Legislacji o jakości procesu legislacyjnego na podstawie obserwacji prowadzonej w okresie od 16 listopada 2017 do 15 maja 2018 roku, Fundacja im. Stefana Batorego, Warszawa 2018, http://www.batory.org.pl/upload/files/Programy proc.20operacyjne/Forum proc.20Idei/XI_Komunikat_OFL.pdf (dostęp: marzec 2020). 
wskazywanym od lat problemom sektora obywatelskiego - zbyt dużemu uzależnieniu organizacji od wsparcia publicznego i ich oddzieleniu od społeczeństwa" ${ }^{32}$. Pierwsza tendencja to gotowość do samoorganizacji i tworzenie koalicji tematycznych, druga - którą wyraźnie zaobserwowałyśmy także w naszych badaniach - dotyczy większego otwarcia na obywateli i budowania lub poszerzania kręgów swoich zwolenników, między innymi poprzez zwiększenie gotowości do proszenia o pieniądze ${ }^{33}$.

\section{Co łączy, co dzieli, co różni?}

Przywołane wyżej wnioski innych badaczy stanowiły istotny punkt odniesienia dla naszego autorskiego badania, które ze względu na ograniczony zasięg miało charakter eksploracyjny, a wnioski stanowią raczej inspirację do dalszych pogłębionych badań niż skończony materiał przynoszący wyczerpującą diagnozę skutków „dobrej zmiany” dla sektora pozarządowego.

Zacznijmy od zastosowanej przez nas metodologii ${ }^{34}$. Badanie objęło dwa etapy. Ilościowe badanie ankietowe organizacji infrastrukturalnych dotyczyło oceny skutków zmian w działaniach zarówno własnych organizacji, jak i tych, na których rzecz pracują; proszono też o wskazanie konkretnych organizacji, które doświadczyły zmian - na lepsze i na gorsze - od 2015 roku. Badanie jakościowe organizacji wyłonionych na podstawie danych zebranych w badaniu ilościowym miało formę pogłębionych wywiadów tematycznych, które zostały przeprowadzone z przedstawicielami organizacji najczęściej wskazywanych jako te, których „sytuacja się polepszyła” oraz tych, których, zdaniem respondentów z części ilościowej, „sytuacja się pogorszyła”. Należy podkreślić, że pojęcia „organizacji, której sytuacja się polepszyła” i „organizacji, której sytuacja się pogorszyła” miały w badaniu wyłącznie walor operacyjny, wynikały ze wskazań uzyskanych w badaniu ilościowym.

32 F. Pazderski, Organizacje obywatelskie..., s. 118.

33 www.funduszobywatelski.pl (dostęp: marzec 2020).

34 W odniesieniu do wcześniej przywoływanych badań informacje na ten temat znajdują się w opublikowanych raportach, ale podejścia zastosowane w tych projektach nie stanowiły podstawy dla podejmowanych przez nas decyzji w kwestii metodologii. 
Przeprowadzone przez nas badania pokazały, że w opiniach „organizacji, których sytuacja się polepszyła” i „organizacji, których sytuacja się pogorszyła" istnieją punkty styczne. Nie spodziewałyśmy się tak bardzo zbliżonych ocen powołania Narodowego Instytutu Wolności (przedstawiciele obu grup uznali to za ważne wydarzenie dla trzeciego sektora w Polsce), zgodnego dostrzegania wzrastającego wsparcia dla organizacji lokalnych i organizacji działających na rzecz osób wykluczonych, bezdomnych, rodzin wielodzietnych oraz ogólnie pozytywnej oceny nowych programów finansujących działania rozwojowe i infrastrukturalne organizacji. Wśród badanych panowała też zgoda w kwestii znaczenia misji w działaniach w obu grupach podkreślano jej duże znaczenie jako niezależnego od sytuacji politycznej klucza do skutecznego działania i radzenia sobie z przeciwnościami. To bardzo istotny wynik. Przez całe lata sformułowanie „misja organizacji” stanowiło raczej synonim obowiązkowej formuły w składanych wnioskach o finansowanie, a nie przedmiot pogłębionej refleksji w organizacjach. Wygląda na to, że ostatnie lata zmusiły organizacje do zmiany podejścia: misja okazuje się teraz kluczem do całej działalności. Być może jest to wynik swoistego pryncypialnego testu, jakiemu - podobnie jak całe społeczeństwo - poddawane są osoby zaangażowane w działania obywatelskie.

Potem jednak zaczynają się już rozbieżności. Wprawdzie zgodnie wskazywano organizacje, które w wyniku działań obecnej władzy straciły, w tym działające na rzecz wszelkich grup mniejszościowych i defaworyzowanych (kobiet - zwłaszcza w kontekście przemocy, osób LGBT, cudzoziemców i cudzoziemek, uchodźców i uchodźczyń), jednak oceny tego faktu były całkowicie odmienne. A zatem: wszyscy badani dostrzegali, że zmiana władzy w 2015 roku spowodowała zmianę jednoznacznie inicjowaną politycznie, opartą na przemyślanej strategii w sytuacji konkretnych grup organizacji. Jednak „organizacje, którym się polepszyło” uważają, że jest to po prostu sprawiedliwość dziejowa, że wcześniej ich punkt widzenia był marginalizowany, a teraz przyszedł ich czas. Co ciekawe, przedstawiciele tej grupy organizacji nie deklarują, że sprzyjają rządowi - twierdzą, że są neutralne i reprezentują centrum. Jednocześnie jednak znacząco lepiej oceniają swoją sytuację i, co bardzo istotne, zwykle deklarują stabilną sytuację finansową - nie ukrywając, że ma to związek z łatwiejszym dostępem do środków publicznych oraz do osób decyzyjnych w instytu- 
cjach rządowych. Konsekwencją jest ich przekonanie, że ani organizacje, ani odbiorcy ich działań nie stracili na zmianie rządu w 2015 roku (z wyjątkiem dwóch organizacji w tej grupie, z których jedna uważa, że jest przedmiotem bezpodstawnej nagonki, a fakt, że organizacja ta po 2015 roku jest wspierana szerokim strumieniem środków publicznych wynika z faktu, że zbiegło się to w czasie z profesjonalizacją i rozwojem organizacji, a druga uważa, że wprawdzie po 2015 roku zyskała, ale gdy rządzący zdali sobie sprawę, że organizacja także nowej władzy patrzy na ręce, to polityka wobec niej natychmiast się zmieniła). „Organizacje, których sytuacja się pogorszyła" jednoznacznie deklarują, że są w stosunku do obecnej władzy w opozycji i swoją sytuację postrzegają zgoła odmiennie: wskazują, że na skutek zmiany władzy utraciły poczucie bezpieczeństwa, a także doświadczają odpływu kadry, co wprost wynika z nieprzewidywalności działań podejmowanych przez instytucje publiczne. Przeżywały lub wciąż przeżywają kryzys bezpośrednio zagrażający ich istnieniu oraz wymuszający myślenie o przyszłości w kategoriach bezpieczeństwa działania i planowania strategicznego. Pośrednim skutkiem takiego stanu rzeczy jest zachwianie wiary w państwo prawa i jego mechanizmy kontrolne.

Badania wskazały, że przedstawiciele obu grup organizacji różnią się istotnie w ocenie sytuacji całego sektora obywatelskiego, a nawet społecznych i politycznych zagadnień ogólniejszej natury. Te, których „sytuacja się polepszyła” uważają, że ogólnie sektor zyskał, „ma się lepiej”, do głosu dopuszczono organizacje wcześniej marginalizowane (jednak zmiana ta nie wynika bezpośrednio z działań władzy, ale jest skutkiem pozytywnych zmian w samym sektorze), poprawił się dostęp organizacji do środków publicznych oraz przejrzystość ich przyznawania, odbiorcy działań nie stracili, głos organizacji jest lepiej słyszany przez władze, podniósł się poziom debaty publicznej dotyczącej spraw obywatelskich. Wskazywano także, iż poprawił się stan państwa prawa, między innymi dzięki reformie sądownictwa i systemu wyborczego i w efekcie pozycja Polski w Unii Europejskiej jest mocniejsza niż wcześniej. „Organizacje których sytuacja się pogorszyła” widzą te zagadnienia zgoła odmiennie. Zdaniem ich przedstawicieli w wyniku działań władz - między innymi ze względu na trudniejszy i mniej przejrzysty dostęp do finansów publicznych, a także ograniczanie konsultacji społecznych jako jeden z przejawów obniża- 
nia poziomu debaty publicznej - sytuacja organizacji pozarządowych w Polsce uległa pogorszeniu. Gorzej mają się też beneficjenci ich działań. Podkreślano jednak, że organizacje starają się utrzymać swoje wsparcie, między innymi przez dywersyfikację źródeł finansowania oraz większą dbałość o poparcie społeczne. Dostrzeganie kryzysu w organizacjach wiązane jest jednoznacznie z gorszym stanem państwa prawa oraz gorszą pozycją Polski w Unii Europejskiej.

W tym miejscu należy wyraźnie podkreślić silne powiązanie sytuacji sektora pozarządowego z reakcją społeczną na ten fakt, co można uznać za swoisty przejaw ogólniejszych podziałów w polskim społeczeństwie. Za przejaw jednoznacznego opowiedzenia się części obywateli po stronie organizacji, które w wyniku politycznej decyzji straciły - albo fundusze, albo, jak w przypadku Wielkiej Orkiestry Świątecznej Pomocy, niektóre możliwości organizacyjne (poprzez wycofanie zaangażowania wielu instytucji publicznych, między innymi służb mundurowych) - można uznać zwiększone finansowanie społeczne. W kolejnych latach WOŚP bije kolejne rekordy w zbiórkach, rosną wpływy z jednego procenta podatku między innymi dla organizacji jednoznacznie skonfliktowanych z rządzącymi $^{35}$, pojawiają się też znacznie wyższe wpłaty pochodzące wprost z kieszeni obywateli, nie tylko w ramach organizowanych zbiórek publicznych. Czasem impulsem bywa nawet atak konkretnego polityka, aby na konto zaatakowanej organizacji zaczęły wpływać sumy wcześniej niedostępne. W rezultacie sytuacja polityczna przyśpieszyła uniezależnianie się wielu organizacji, które po wygranych przez $\mathrm{PiS}$ wyborach walczyły o przetrwanie, między innymi dlatego, że ich trudna sytuacja zaktywizowała darczyńców, przysporzyła im sojuszników i sojuszniczek.

Niezależnie od różnic metodologicznych w obu etapach naszego badania, można stwierdzić, że wyniki uzyskane na podstawie badania jakościowego dobrze korespondują z tym, co udało się wywnioskować z badania ilościowego. Wśród negatywnych konsekwencji, które dotknęły organizacje pozarządowe po 2015 roku można wskazać utrudnienia biurokratyczne

35 Redakcja ngo.pl, 2 października 2018, 1 proc. podatku dla OPP w 2018 r. To jest rekordowy rok!, https://publicystyka.ngo.pl/1-podatku-dla-opp-w-2018-r-to-jest-rekordowy-rok (dostęp: marzec 2020). 
i wydłużenie procedur, preferowanie działań zgodnych z linią rządu oraz utrudnienia dla „nieprawomyślnych” organizacji, nietransparentne finansowanie, a także antagonizowanie środowiska. Badani często nie wskazywali żadnych jednoznacznie pozytywnych skutków, a gdy jednak takie sygnalizowali, to dotyczyły one ułatwień w dostępie do funduszy małych lokalnych organizacji, przeniesienia na wyższy (rządowy) szczebel kwestii działania organizacji pozarządowych, zmian w procedurach konkursowych oraz reakcji środowiska NGO i społeczeństwa na działania władz.

Wyniki uzyskane w naszych badaniach w znacznym stopniu potwierdzają wcześniejsze - naukowe i publicystyczne - analizy sytuacji polskich organizacji pozarządowych po 2015 roku. Za najważniejszy nowy wątek trzeba uznać pewne przejawy paradoksalnie pozytywnych konsekwencji niezamierzonych przez władze - chociaż musimy przyznać, że jest to raczej nasza hipoteza stanowiąca ważne pytanie badawcze dla dalszych analiz. Chodzi o konsolidację i swoistą samoorganizację części środowiska, przede wszystkim w ramach tej części organizacji, które pozytywnych skutków „dobrej zmiany” nie odczuwają. Nie bez znaczenia jest też budzący nadzieję zwrot w kierunku większego skupienia na odbiorze społecznym i budowaniu relacji zarówno $\mathrm{z}$ adresatami działań, jak i z darczyńcami, a także ograniczania uzależnienia od pieniędzy publicznych, które od zawsze było istotną bolączką polskiego sektora pozarządowego.

\section{Podsumowanie}

Powstaje pytanie o dalekie, obecnie trudno przewidywalne skutki tak silnych podziałów. Mimo wskazanej hipotezy o rodzącej się współpracy, wciąż jednak jest to raczej współpraca w ramach dwóch wrogich obozów. Trudno bowiem sobie dzisiaj wyobrazić jakiekolwiek przejawy solidarności podmiotów społeczeństwa obywatelskiego wokół takich wartości jak różnorodność światopoglądowa (i wszelka inna), otwartość, gotowość do zaakceptowania istnienia innych poglądów bez konieczności zgadzania się z nimi. Obecnie w sektorze organizacji pozarządowych istnieją dwa wrogie obozy, niemal dokładnie odzwierciedlające głęboki podział w całym społeczeństwie.

Jedną z większych słabości polskiego trzeciego sektora wciąż pozostaje jego „wsobność”, rozumiana nie jako niedostateczna współpraca z inny- 
mi podmiotami, ale jako brak silnego osadzenia społecznego, na przykład w społecznościach lokalnych czy różnego rodzaju środowiskach. Odzwierciedlenie w organizacjach - co bardzo ważne: nie wszystkich, lecz tych, które na różne sposoby angażują się lub doświadczają skutków sporu politycznego - istniejącego podziału społecznego stwarza szansę na to, że wprawdzie sektor pozarządowy pozostanie w znacznym stopniu podzielony, ale ten podział częściowo zastąpi dotychczasowe rozkawałkowanie na niezliczone elementy.

Powstaje jednak ważne pytanie aksjologiczne: co ze wspólnotą? Wspólnotą w polskim społeczeństwie i wspólnotą ludzi społecznie zaangażowanych? Niestety, trudno przewidywać, aby po tym wszystkim, co się stało i co zostało powiedziane, możliwy był powrót choćby do takiej - nieco iluzorycznej - wspólnoty, jakiej doświadczaliśmy choćby stając się członkiem Unii Europejskiej. Wygląda na to, że najlepsze, na co można liczyć, to sektor pozarządowy wprawdzie podzielony, ale zgodnie z realnym podziałem całego społeczeństwa, ergo: $\mathrm{z}$ większą szansą na realne osadzenie społeczne, realne oddziaływanie, rzeczywiste realizowanie wyznawanych na serio wartości.

$\mathrm{Na}$ koniec warto się odwołać do ostatnich doświadczeń polskiego społeczeństwa będących skutkiem pandemii Covid-19. Skutki tej sytuacji istotnie wpłynęły również na sposób funkcjonowania organizacji pozarządowych, a także na szeroko rozumiane kwestie zaangażowania społecznego i wspólnotowości. Wiele informacji na ten temat dostarcza badanie Stowarzyszenia Klon/Jawor pt. „Organizacje wobec pandemii”, które pozwoliło na wyodrębnienie zupełnie nowych kategorii organizacji, określonych jako „zamrożone”, „walczące”, „zmobilizowane”36. Można przypuszczać, że pogłębiona - uwzględniająca zarówno okoliczności polityczne, jak i postpandemiczne - analiza obecnej sytuacji polskiego sektora pozarządowego może prowadzić do zarysowania jego zniuansowanego i bogatszego obrazu Anno Domini 2020.

36 B. Charycka, Pod lupa: Zamrożone, walczace, zmobilizowane. Pierwsze wyniki badania „Organizacje wobec pandemii”, Stowarzyszenia Klon/Jawor, https://publicystyka.ngo.pl/zamrozone -walczace-zmobilizowane-pierwsze-wyniki-badania-organizacje-wobec-pandemii-stowarzyszenia-klon-jawor (dostęp: czerwiec 2020). 


\section{Bibliografia}

1 proc. podatku dla OPP $w 2018$ r. To jest rekordowy rok!, ngo.pl, 2 października 2018, https://publicystyka.ngo.pl/1-podatku-dla-opp-w-2018-r-to-jest-rekordowy-rok.

[adm], Lista Przebojów Trójki zawieszona. Ale wygrat Kazik, „Rzeczpospolita”, 22 maja 2020, dostępne na: https://www.rp.pl/Media/200529718-ListaPrzebojow-Trojki-zawieszona-Ale-wygral-Kazik.html.

Arczewska M., Charycka B., Gumkowska M., Kondycja organizacji równościowych. Raport z badań 2019, Stowarzyszenie Klon/Jawor, Warszawa 2019, dostępne na: https://api.ngo.pl/media/get/110722.

Charycka B., Pod lupa: zamrożone, walczace, zmobilizowane. Pierwsze wyniki badania "Organizacje wobec pandemii”, Stowarzyszenie Klon/Jawor, Warszawa, 29 kwietnia 2020, https://publicystyka.ngo.pl/zamrozone-walczace -zmobilizowane-pierwsze-wyniki-badania-organizacje-wobec-pandemii -stowarzyszenia-klon-jawor.

Charycka B., Zmobilizowane przez trudności, ngo.pl, 3 kwietnia 2019, https:// publicystyka.ngo.pl/zmobilizowane-przez-trudnosci, ngo.pl.

Charycka B., Gumkowska M., Kondycja organizacji pozarzadowych. Raport $z$ badań 2018, Stowarzyszenie Klon/Jawor, Warszawa 2019, dostępne na: https://api.ngo.pl/media/get/108227.

Cypryańska-Nezlek M., Wyzwania i zagrożenia pracy w NGO $i$ nieformalnych ruchach społecznych. Raport $z$ badania, Biuro Rzecznika Praw Obywatelskich, 25 lutego 2020, https://www.rpo.gov.pl/sites/default/files/Raport\%20 z\%20badania\%20Marzena\%20Cyprya\%C5\%84ska-Nezlek_0.pdf.

Fakty o NGO, ngo.pl, https://fakty.ngo.pl/.

Flieger E., „To Muzeum powinno być duma." Proces pokazuje, jak prawica niszczyła Muzeum II Wojny Światowej, OKO.Press, 24 listopada 2019, https:// oko.press/to-muzeum-powinno-byc-duma-proces-pokazuje-jak-prawicaniszczyla-muzeum-ii-ws/.

Gliński P., Palska H., Cztery wymiary spotecznej aktywności obywatelskiej, w: H. Domański, A. Rychard (red.), Elementy nowego ładu, Instytut Filozofii i Socjologii PAN, Warszawa 1997.

Górska P., Polaryzacja polityczna w Polsce. Jak bardzo jesteśmy podzieleni?, Centrum Badań nad Uprzedzeniami, Warszawa 2019, dostępne na: https:// docplayer.pl/115461613-Polaryzacja-polityczna-w-polsce-jak-bardzojestesmy-podzieleni-paulina-gorska.html. 
Jethon M., Czajkowski M., Media publiczne w Polsce to sa media rzadowe, Koduj24.pl, 24 czerwca 2019, https://koduj24.pl/maciej-czajkowski-mediapubliczne-w-polsce-to-sa-media-rzadowe/.

Kopińska G. (red.), XI Komunikat Obywatelskiego Forum Legislacji o jakości procesu legislacyjnego na podstawie obserwacji prowadzonej $w$ okresie od 16 listopada 2017 do 15 maja 2018 roku, Fundacja im. Stefana Batorego, Warszawa 2018, http://www.batory.org.pl/upload/files/Programy proc.20operacyjne/Forum proc.20Idei/XI_Komunikat_OFL.pdf.

Kośmiński P., Ustawa o Narodowym Instytucie Wolności czeka na podpis Andrzeja Dudy. NGO-sy apeluja o kolejne weto, Wyborcza.pl, 6 października 2017, https://wyborcza.pl/7,75398,22476571,apel-do-andrzeja-dudy-o-zawetowanie-ustawy-o-ngo-sach-grozi.html.

Kryszkiewicz M., Osiecki G., Dokąd zmierzamy w sporze o sady? 12 pytań $i$ odpowiedzi dotyczacych uchwaty Sadu Najwyższego, "Gazeta Prawna”, 27 października 2020, dostępne na: https://prawo.gazetaprawna.pl/artykuly/1450531,uchwala-sadu-najwyzszego-spor-o-sady.html.

Kurczewski J., Lokalne społeczeństwa obywatelskie, w: J. Kurczewski (red.), Lokalne społeczności obywatelskie, Instytut Stosowanych Badań Społecznych, Warszawa 2003.

Matka Kurka [Piotr Wielgucki], Gorzej niż za komuny, powiedziat aktor z PRL-u, Kontrowersje.net, 1 maja 2018, https://www.kontrowersje.net/gorzej_ni_ za_komuny_powiedzia_aktor_z_prl_u.

[MK] Demonstracja poparcia dla reformy sqdownictwa. „Jako spoteczeństwo musimy coś zrobić", TVP Info, 2 lutego 2020, https://www.tvp.info/46470541/ demonstracja-poparcia-dla-reformy-sadownictwa-jako-spoleczenstwomusimy-cos-zrobic.

Obacz P., Podziat spoteczno-polityczny w Polsce - wymiar aksjologiczny. Istota, konsekwencje, prognozy, w: E. Starzyńska-Kościuszko (red.): Wartości i wartościowanie we wspótczesnej humanistyce. Perspektywa filozoficzna, Centrum Badań Europy Wschodniej Uniwersytetu Warmińsko-Mazurskiego, Olsztyn 2017.

Pawlak M., List socjologów do wicepremiera Glińskiego w sprawie demokracji, petycjeonline.com, styczeń 2016, https://www.petycjeonline.com/list_socjologow_do_wicepremiera_glinskiego_w_sprawie_demokracji.

Pazderski F., Organizacje obywatelskie w Polsce wobec wyzwań spoteczno-politycznych i nowych trendów w ich rozwoju, w: R. Boguszewski (red.): Spoteczeństwo obywatelskie w teorii i praktyce, Wydawnictwo Szkoły Głównej Gospodarstwa Wiejskiego, Warszawa 2018.

Prawo o szkolnictwie wyższym i nauce, Konstytucja dla Nauki, https://konstytucjadlanauki.gov.pl/. 
Radkiewicz P., Wzorce preferowanych wartości a wybory polityczne. O aksjologicznych przesłankach polaryzacji politycznej Polaków, w: A. Pytka, K. Maciąg (red.): Rozważania na temat kondycji polskiego społeczeństwa, Wydawnictwo Naukowe Tygiel, Lublin 2018, s. 34, dostępne na: http://bc.wydawnictwotygiel.pl/public/assets/239/Rozwa proc.C5 proc.BCania proc.20na proc. 20temat proc.20kondycji proc.20polskiego proc.20spo proc.C5 proc.82ecze proc.C5 proc.84stwa.pdf.

Rutkowska E., Piotr Battroczyk nie chce występować w TVP rządzonej przez Jacka Kurskiego, Press, 10 maja 2016, https://www.press.pl/tresc/43834,piotr-baltroczyk-nie-chce-wystepowac-w-tvp-rzadzonej-przez-jacka-kurskiego.

Sarzyński P., Prof. Miziołek niczym tajfun rujnuje Muzeum Narodowe, „Polityka”, 11 lipca 2019, dostępne na: https://www.polityka.pl/tygodnikpolityka/kultura/1799838,1,prof-miziolek-niczym-tajfun-rujnuje-muzeum-narodowe. read.

Sawczuk T., Kampania prezydencka to strata czasu, „Kultura Liberalna” 2020, nr 8, dostępne na: https://kulturaliberalna.pl/2020/03/02/sawczuk-w-poniedzialek-kampania-prezydencka-to-strata-czasu/.

Siciński A., Społeczeństwo obywatelskie a polskie transformacje ustrojowe, w: E. Muszyńska, I. Pielak (red.), Ludzie i instytucje. Stawanie się ładu spoŁecznego. Pamiętnik IX Ogólnopolskiego Zjazdu Socjologicznego, Wydawnictwo Uniwersytetu Marii Curie-Skłodowskiej, Lublin 1995.

Spór o dyrektora Polin: Ministerstwo Kultury odpowiada na oświadczenie Dariusza Stoli, Onet Kultura, 11 lutego 2020, https://kultura.onet.pl/wiadomosci/spor-o-dyrektora-polin-ministerstwo-kultury-odpowiada-na-oswiadczenie-dariusza-stoli/9h33y8v.

Szacki J., Historia myśli socjologicznej. Wydanie nowe, Wydawnictwo Naukowe PWN, Warszawa 2002.

[tmw/kg], Protesty w obronie sądów w polskich miastach. Zobacz, jak wygladaty, TVN24.pl, 18 grudnia 2019, https://tvn24.pl/polska/protesty-w-obroniewolnych-sadow-demonstracje-w-polskich-miastach-ra994396-2608984.

Uchwata nr 01/12/2017 Rady Wydziatu Prawa i Administracji Uniwersytetu Warszawskiego w sprawie apelu do Prezydenta Rzeczypospolitej Polskiej, Wydział Prawa i Administracji Uniwersytetu Warszawskiego, http://strony.wpia. uw.edu.pl/zarzadzeniauchwaly/files/2017/12/201712201444_0001.pdf.

Wojciechowski K., Dobra zmiana w kulturze: Pomnażać $i$ centralizować, Dziennik.pl, 4 października 2019, https://kultura.dziennik.pl/news/artykuly/609380,dobra-zmiana-kultura-piotr-glinski.html.

Wybory do Sejmu i Senatu Rzeczypospolitej Polskiej 2019, Państwowa Komisja Wyborcza, https://sejmsenat2019.pkw.gov.pl/sejmsenat2019/. 


\section{Civic Sector and Civic Activists in Times of 'Good Change': Discussions - Tensions - Conflicts}

Changes that occurred in Poland between 2015 and 2019 have not spared the civil society, here understood broadly as NGOs, activist groups, independent academic organisations and minority communities. This paper is an attempt at reconstructing key ideological arguments that took place within it during that time, as well as their significance and effects on particular organisations both internally and in relation with other participants in the civil society. Also investigated are divisions that arose and their potential consequences in the future. The analysis is based on research by Magdalena Arczewska and Magdalena Dudkiewicz and published as Strategie czy przystosowanie? Sytuacja organizacji pozarzadowych w Polsce po 2015 [Strategies or Adaptation? The Situation of Non-governmental Organizations in Poland after 2015] (Kraków: Wydawnictwo Impuls, 2019).

\section{Keywords:}

NON-GOVERNMENTAL ORGANiSATIONS (NGOS), SOCIAL POLARISATION, COMMUNITY. 